\title{
ARTIKELEN
}

\section{Samenhang in beleid op het terrein van veilig- heid en justitie}

\author{
Een longitudinale analyse van de geleverde prestaties per \\ bestede euro in de V\&J-sector in de periode 1980-2016
}

Jos Blank \& Alex van Heezik

\begin{abstract}
Op het beleidsterrein veiligheid en justitie is sprake van een sterke onderlinge verwevenheid tussen de prestaties van de verschillende sectoren, zoals de politie, de rechterlijke macht en het gevangeniswezen. De vraag is of het beleid daar voldoende rekening mee houdt. Worden de ingezette middelen vanuit een breder welvaartsperspectief optimaal gealloceerd over de verschillende veiligheids- en justitievoorzieningen? De auteurs beantwoorden deze vraag aan de hand van een integrale tijdreeksanalyse van de productiviteitsontwikkeling van het Nederlandse veiligheids- en justitiesysteem in de periode 1980-2016.

Uit de analyse blijkt dat de productiviteit van de dienstverlening op het terrein van veiligheid en justitie sinds 1980 nauwelijks verandert. In het gunstigste geval krijgt de burger in 2016 nog evenveel 'waar' geleverd per euro belastinggeld als in 1980, maar waarschijnlijk iets minder. Opvallend is wel dat het V\&J-systeem als geheel beter functioneert dan de som der delen (de afzonderlijke sectoren). In de allocatie van middelen verandert wel het nodige in de loop der tijd. De politie levert duidelijk in ten gunste van de rechterlijke macht en gemeenten.
\end{abstract}

\section{$1 \quad$ Inleiding}

\subsection{Introductie}

Het functioneren van een (publieke) sector is eigenlijk nooit geheel los te zien van ontwikkelingen die bij andere sectoren op eenzelfde beleidsterrein plaatsvinden. Op het gebied van de strafrechtshandhaving is er bijvoorbeeld een heel directe samenhang tussen de opeenvolgende activiteiten en de sectoren die daarvoor verantwoordelijk zijn: opsporing (politie), vervolging (Openbaar Ministerie, OM), berechting (rechtspraak) en sanctietoepassing (Dienst Justitiële Inrichtingen (DJI)/ gevangeniswezen). We spreken dan doorgaans van een keten, waarbij de verschillende schakels in de keten een sterk volgtijdelijke samenhang met elkaar vertonen. Zonder een opgehelderd misdrijf is er geen veroordeling en geen gevangenisstraf. In de hier gepresenteerde tijdreeksanalyse kijken we ook naar samenhangen buiten de bekende strafrechtketen. Er is namelijk ook een samenhang tussen de activiteiten op het gebied van strafrecht en die op andere onderdelen van het beleidsterrein veiligheid en justitie. Zo houdt de politie zich niet alleen bezig met opsporing, 
maar ook met de handhaving van de openbare orde en hulpverlening. Als de politie veel opsporingsactiviteiten verricht, dan kan dat ten koste gaan van deze taken. Het omgekeerde geldt natuurlijk ook. De rechtspraak behandelt naast de strafrechtzaken, ook civiele en bestuursrechtelijke zaken. Ligt er veel nadruk op deze zaken, dan kunnen de rechters minder strafzaken afdoen en vice versa.

Elders op het beleidsterrein zijn deze samenhangen eveneens te vinden. Er is bijvoorbeeld een verband tussen de inzet van de brandweer en die van de politie. Maakt de brandweer meer werk van haar preventieve taak en ontstaan daardoor minder branden, dan betekent dat automatisch minder hulpverlening van politie bij branden. Ook als taken en activiteiten inhoudelijk weinig met elkaar te maken hebben, is er een relatie in het systeem. Minder budget voor politie en meer voor de brandweer betekent vanzelfsprekend een verschuiving in de geleverde prestaties, die uit het oogpunt van welvaart al dan niet wenselijk kan zijn. Ook deze minder directe samenhang tussen activiteiten op het beleidsterrein van V\&J nemen we in onze beschouwing mee.

\subsection{Probleemstelling en onderzoeksvragen}

De vraag is of er bij de allocatie van overheidsmiddelen over deze verschillende V\&J-voorzieningen voldoende rekening is gehouden met bovengenoemde samenhang.

Om daarop zicht te krijgen gaan we na welke prestaties er de afgelopen decennia op het totale V\&J-terrein zijn geleverd, welke middelen daarvoor zijn ingezet en waar deze terecht zijn gekomen. De centrale vraagstelling van dit artikel is dan ook:

1 Hoe heeft de productiviteit op het terrein van veiligheid en justitie zich tussen 1980 en 2016 ontwikkeld?

2 Heeft het beleid, in het bijzonder ten aanzien van de allocatie van middelen, hierop invloed gehad?

\subsection{Opzet}

In dit artikel bespreken we eerst in paragraaf 2 de afbakening van het terrein van de V\&J-sector en schetsen we de ontwikkelingen van de belangrijkste prestatie-indicatoren tussen 1980 en 2016. In paragraaf 3 beschrijven we de kostenontwikkeling van de gehele V\&J-sector. Paragraaf 4 gaat vervolgens in op de zogenoemde 'value for money'- of productiviteitsontwikkeling. De laatste paragraaf bevat de belangrijkste conclusies. Een uitgebreide toelichting op dit onderzoek is te vinden in Blank \& Van Heezik (2019).

\section{Prestaties veiligheid en justitie}

\subsection{Kerntaken veiligheid en justitie}

Over de kern van de veiligheids- en justitietaken kan nauwelijks misverstand bestaan. Zoals de naam al aangeeft, zijn alle activiteiten uiteindelijk gericht op de zorg voor een veilige en rechtvaardige samenleving. Deze activiteiten vinden voor een belangrijk deel plaats binnen de zogenoemde strafrechtketen. Zij worden doorgaans onderverdeeld in de clusters: preventie, opsporing, vervolging, berechting 
en tenuitvoerlegging. De uitvoering van deze taken is grotendeels in handen van de belangrijkste drie sectoren op het beleidsterrein: de politie, rechterlijke macht (Openbaar Ministerie en de Rechtspraak) en de Dienst Justitiële Inrichtingen (DJI), waaronder met name het gevangeniswezen.

De politie en rechtspraak zijn niet alleen actief in de strafrechtketen, maar voeren ook allerlei activiteiten uit op andere gebieden van het V\&J-beleidsterrein. De politie speelt bijvoorbeeld ook een rol bij het handhaven van de openbare orde en bij de hulpverlening aan burgers. En behalve met strafzaken houdt de rechtspraak zich bezig met het beslechten van geschillen tussen burgers en organisaties onderling, organisaties (vooral bedrijven) onderling en tussen burgers en organisaties. Dit zijn civielrechtelijke zaken. Daarnaast behandelt de rechtspraak bestuursrechtelijke zaken: geschillen over besluiten van bestuursorganen.

Naast de genoemde activiteiten worden er op het terrein van veiligheid en justitie nog veel andere taken uitgevoerd, zoals door organisaties als Reclassering Nederland, het Nederlands Forensisch Instituut en de Douane. Van de meeste van deze organisaties zijn echter geen of onvoldoende productie- en middelengegevens beschikbaar. Zij blijven dan ook buiten beschouwing. Wel betrekken we de lokale V\&J-activiteiten in onze analyse. Dat zijn de activiteiten van de gemeenten op het gebied van brandweer, rampenbestrijding en openbare orde en veiligheid. De analyse bestrijkt dus niet het volledige terrein van veiligheid en justitie, maar wel het overgrote deel daarvan. De uitgaven van de in de analyse betrokken sectoren beslaan ongeveer $90 \%$ van de totale overheidsuitgaven aan veiligheid en justitie.

\subsection{V\&J-productie}

Bij de keuze voor de productie-indicatoren zijn we uitgegaan van vijf hoofdtaken voor het gehele V\&J-systeem. Tabel 1 noemt de vijf hoofdtaken met de daarbij behorende productie-indicatoren.

Tabel 1 Overzicht hoofdtaken en productie-indicatoren veiligheid en justitie

\begin{tabular}{ll}
\hline Hoofdtaken & Productie-indicator \\
\hline $\begin{array}{l}\text { handhaving van de openbare orde } \\
\text { preventie van misdrijven en ongevallen }\end{array}$ & $\begin{array}{l}\text { geen (vast aandeel) } \\
\text { misdaadpreventie op basis van een demografi- } \\
\text { sche en sociaaleconomische proxy }\end{array}$ \\
hulpverlening bij ongevallen en calamiteiten & $\begin{array}{l}\text { antal gevallen van hulpverlening (brandweer- } \\
\text { hulp en verkeersongevallen met doden en }\end{array}$ \\
& $\begin{array}{l}\text { gewonden) } \\
\text { afgehandelde civiele en bestuursrechtelijke } \\
\text { zeschillenbeslechting tussen burgers (particu- }\end{array}$ \\
$\begin{array}{l}\text { lieren en bedrijven) onderling en tussen } \\
\text { burgers en overheid }\end{array}$ & $\begin{array}{l}\text { opgelegde transacties (inclusief Wahv- en } \\
\text { strafbeschikkingen) en schuldigverklaringen } \\
\text { strafoplegging }\end{array}$ \\
$\begin{array}{l}\text { door rechtbank (exclusief instroom gevangenis- } \\
\text { wezen); aantal gedetineerden (of instroom } \\
\text { gedetineerden) }\end{array}$ \\
\hline
\end{tabular}

Handhaving van de openbare orde betreft het optreden van de politie bij een burenruzie tot en met de beheersing van grootschalige evenementen (voetbalwed- 
strijden). Tijdreeksgegevens hierover zijn echter niet beschikbaar. We veronderstellen daarom dat deze activiteit een vrij constante factor in de tijd is en bovendien een relatief lage inzet van middelen vereist, al lijkt dit optisch anders. Uit een studie van Urlings et al. (2014) blijkt dat de politie zijn budget voor meer dan $90 \%$ besteedt aan opsporing, preventie en hulpverlening. Handhaving is daarom in de analyse buiten beschouwing gelaten. Het is de vraag of bij een eventuele toekomstige analyse deze veronderstelling over 2020 standhoudt. Door het wegvallen van veel evenementen is er veel minder politie-inzet nodig geweest. Daar staat tegenover dat de politie en boa's een grotere inspanning hebben moeten leveren om de coronaregels te handhaven.

Preventie van criminaliteit en ongevallen is een lastig te meten activiteit. Voor de preventie van criminaliteit hanteren we daarom een proxy, gebaseerd op het verschil tussen verwachte en feitelijke criminaliteit. Hoe groter het verschil, des te groter is de preventieactiviteit geweest. Overigens is de politie natuurlijk niet alleen verantwoordelijk voor een lagere criminaliteit. Ook allerlei andere preventieve maatregelen, van overheid of van particulieren, kunnen dit cijfer beïnvloeden. Ook het zogenoemde insluitingseffect (criminelen die vastzitten kunnen geen misdrijven begaan) kan een rol spelen. De verwachte criminaliteit is een uitvloeisel van een microanalyse waarbij de criminaliteit wordt gekoppeld aan demografische en sociaaleconomische kenmerken. Voor details verwijzen we graag naar Urlings et al. (2014).

Preventie is niet alleen gericht op het tegengaan van de criminaliteit, maar ook op het voorkómen van ongevallen. Daarbij gaat het vooral om verkeersongevallen. Het effect van maatregelen als controles op snelheid, rijden door rood licht en rijden onder invloed op het aantal verkeersongevallen is echter moeilijk vast te stellen. In vergelijking met andere factoren die van invloed zijn op de verkeersveiligheid lijkt de bijdrage vrij beperkt. Uit de literatuur (Aarts, 2018; Bax, 2012; Wijnen et al., 2013) blijkt dat vooral maatregelen op het gebied van de infrastructuur een belangrijke rol spelen bij de verbetering van de verkeersveiligheid. Dat geldt ook voor maatregelen als de verplichtstelling van beveiligingsmiddelen, zoals autogordels en helmen, en voor de verbeterde veiligheid van de voertuigen. Dit aspect van preventie blijft hier verder buiten beschouwing.

De inzet aan hulpverlening meten we af aan het aantal brandmeldingen en andere hulpvragen aan de brandweer én het aantal gewonden en doden bij verkeersongevallen. Bij dit soort ernstige verkeersongevallen is vrijwel altijd sprake van hulpverlening door de politie. De hulpverlening van de brandweer heeft ook betrekking op de politie, omdat de politie hierbij dikwijls assistentie verleent. Het gaat hier wel om een beperkt deel van de hulpverlening door de politie. De politie verleent namelijk ook hulp bij tal van andere incidenten, zoals bij (meldingen van) onwel worden of overlijden van burgers, vermiste personen en bedreigingen.

Een andere belangrijke activiteit op het terrein van veiligheid en justitie betreft de geschillenbeslechting tussen burgers (particulieren en bedrijven) onderling en tussen burgers en de overheid. Het aantal door de rechter behandelde civiele en bestuursrechtelijke zaken dient hier als indicator. 
De samenhang tussen de prestaties van de verschillende sectoren binnen het V\&J-beleidsterrein komt het meest tot uitdrukking in de strafoplegging. Dit is immers de resultante van de prestaties van politie, rechterlijke macht en gevangeniswezen, die elkaar wederzijds beïnvloeden. Omdat er een groot verschil bestaat tussen vrijheidsstraffen en andere vormen van straffen, houden we dit onderscheid ook aan.

De eerste indicator van strafoplegging gaat uit van het aantal opgelegde transacties (door politie en OM, inclusief beschikkingen volgend uit de Wet administratiefrechtelijke handhaving verkeersvoorschriften (Wahv) en strafbeschikkingen) en schuldigverklaringen met oplegging van straf uitgesproken door de rechtbank, verminderd met het aantal uitgesproken onvoorwaardelijke vrijheidsstraffen. Het aantal opgelegde onvoorwaardelijke vrijheidsstraffen meten we af aan de daadwerkelijke instroom van gedetineerden. Door bij de eerste indicator ook uit te gaan van schuldigverklaringen, nemen we dus ook sancties als voorwaardelijke gevangenisstraffen, taakstraffen, geldboetevonnissen en ontzeggingen van de rijbevoegdheid mee in de productiemaat.

De tweede indicator betreft het aantal gedetineerden. Deze grootheid is eigenlijk een maat voor het aantal opgelegde strafjaren. Behalve het aantal opgelegde vrijheidsstraffen komt hierin de gemiddelde casemix (ernst) van de gepleegde misdrijven tot uitdrukking. Een hoger aantal gedetineerden hangt voor een deel samen met de gemiddelde strafmaat. De strafmaat kan echter ook een reflectie zijn van een strenger strafklimaat (meer en zwaardere vrijheidsstraffen). Als we hiermee geen rekening willen houden, zouden we alleen de instroom van gedetineerden als maat moeten hanteren. We laten in dit artikel de resultaten van beide varianten zien.

Zoals eerder aangegeven, is de voorgaande lijst van indicatoren een heel ruwe benadering van de geleverde prestaties. Zo wordt er, behalve bij het aantal gedetineerden, nauwelijks rekening gehouden met de zwaarte van de productie. Door sensitiviteitsanalyses uit te voeren, hebben we nog wel gekeken naar de invloed van de verschillende gewichten voor opgelegde transacties en de schuldigverklaringen op de productiviteit. De resultaten bleken hiervoor nauwelijks gevoelig. Een omissie is dat er geen rekening is gehouden met de preventieve taak van de brandweer en overige gemeentelijke hulpverlening. Verder spelen allerlei tijdsaspecten een rol die tot meetfouten kunnen leiden. Denk bijvoorbeeld aan de inspanningen die de politie in een bepaald jaar levert om een misdrijf op te helderen waarbij het resultaat pas in een volgend of zelfs daaropvolgend jaar wordt geleverd in de vorm van een strafoplegging. Hiervoor zijn geen adequate oplossingen te bedenken. Dit kan de resultaten wel enigszins vertekenen.

Figuur 1 geeft de ontwikkeling weer van de vijf productindicatoren, uitgedrukt in indexcijfers in het basisjaar $1980(=100)$. Een index van 200 in een bepaald jaar betekent dat de productie ten opzichte van 1980 verdubbeld is. 
Figuur 1 Ontwikkeling productie V\&J-sector, 1980-2016 (indexcijfers: $1980=$ 100)

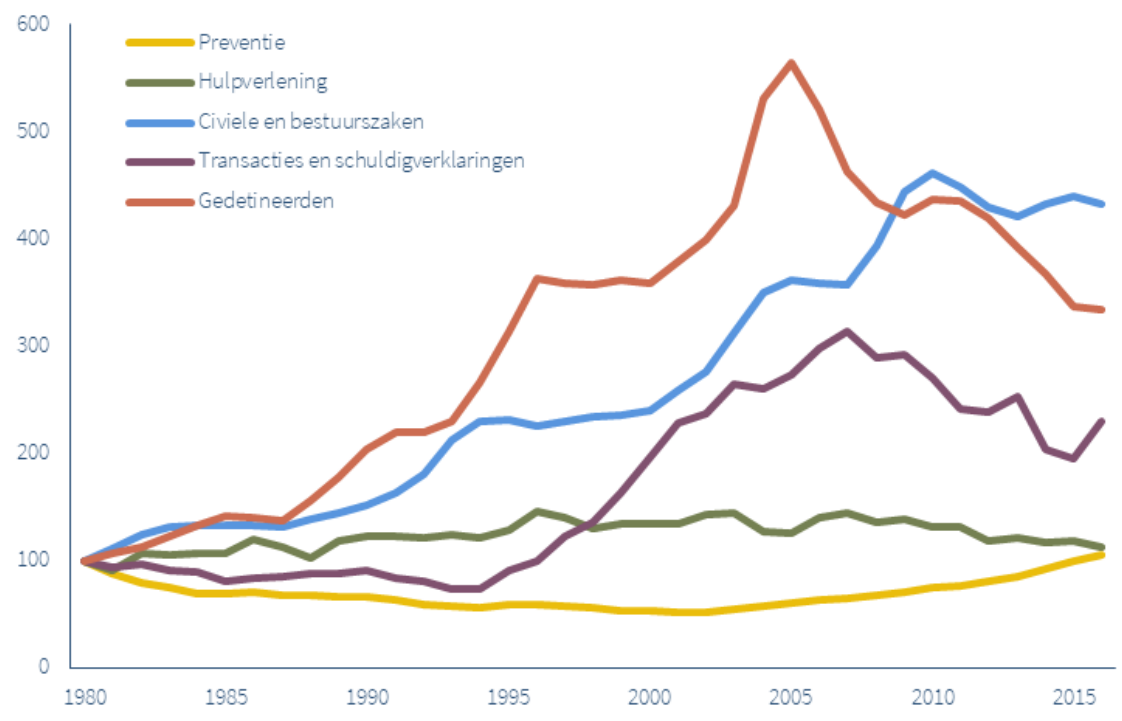

Volgens figuur 1 zijn de activiteiten op het gebied van preventie en hulpverlening in 2016 ten opzichte van 1980 nauwelijks gegroeid. Dit in tegenstelling tot het aantal civiele en bestuursrechtelijke zaken. Over de gehele periode genomen vindt hier de sterkste groei plaats (factor 4,5). Het gaat hier om een heel trendmatige groei tot aan 2010. Behalve de groei van de bevolking spelen andere ontwikkelingen een rol, zoals de toenemende complexiteit van de samenleving, de groei van de welvaart en toename van het aantal transacties, vergrijzing, individualisering en mondigheid. Na 2010 stabiliseert het aantal zaken. Dit hangt onder andere samen met de vanaf 2010 ingevoerde Wet griffierechten burgerlijke zaken (Wgbz), waardoor de griffierechttarieven van civiele zaken flink stijgen. Dit heeft met name een drukkend effect op het aantal handelszaken (Eshuis \& Diephuis, 2018; Van Tulder et al., 2017; Van Tulder, 2014).

Het aantal opgelegde transacties en schuldigverklaringen groeit fors gedurende de gehele periode. In 2016 is dit aantal 2,5 keer zo groot als in 1980. Vooral na 1994 is er een forse groei. Dit is het gevolg van de invoering van de Wahv, beter bekend als de Wet Mulder. Strafrechtzaken over lichte verkeersovertredingen - ook wel 'Mulderfeiten' genoemd - worden voortaan bestuursrechtelijk afgehandeld. De uitvoering daarvan komt in handen van het Centraal Justitieel Incassobureau (CJIB). Het effect van de Wet Mulder, die vanaf 1989 geleidelijk wordt ingevoerd, op de werklast van de rechterlijke macht is groot. Na de volledige inwerkingtreding in 1992 daalt het aantal OM- en kantonzaken sterk (Blank \& Van Heezik, 2017).

Opmerkelijk is ook de meer dan vervijfvoudiging van het aantal gedetineerden tot aan 2005. Deze ontwikkeling is deels een gevolg van de steeds zwaardere straffen 
die worden uitgedeeld, maar ook de instroom neemt door de jaren heen toe. In paragraaf 4 gaan we nader in op deze ontwikkeling.

\subsection{Maatschappelijke ontwikkelingen en de vraag naar veiligheid en justitie}

De feitelijk geleverde en dus waargenomen productie is een uitkomst van vraag en aanbod naar diensten op het terrein van veiligheid en justitie. Politie en brandweer kunnen alleen aan hulpverlening doen als er zich calamiteiten of ongevallen voordoen. Dan bepaalt de vraagzijde de productie.

Aan de andere kant van het spectrum treffen we bijvoorbeeld het aantal opgelegde sancties aan. Er wordt dagelijks zo veel gezondigd tegen de regels dat de vraagzijde nooit de bepalende factor zal zijn. De inzet van de politie bepaalt dan vooral de omvang van de productie. Om de productie wat beter te kunnen begrijpen is het dus belangrijk enig zicht te hebben op de vraagzijde en in het bijzonder op een aantal factoren die de vraag beïnvloeden. We staan hier kort bij stil.

Dat er in het algemeen een forse groei van de productie heeft plaatsgehad, is op zichzelf niet vreemd. Onze samenleving is immers gegroeid, zowel wat betreft bevolking als economische activiteit. Het is dan ook interessant om na te gaan of de productiegroei hiermee gelijke tred houdt en of er sprake is van andere ontwikkelingen die de (gevraagde) productie beïnvloeden. Om hierop enig zicht te krijgen, koppelen we de verschillende productie-indicatoren aan de belangrijkste twee maatschappelijke ontwikkelingen: de bevolkingsgroei en de groei van het bruto binnenlands product (bbp) in constante prijzen. Beide variabelen weerspiegelen het aantal interacties tussen mensen. Die kunnen direct betrekking hebben op het aantal interacties tussen mensen zelf, maar ook op het aantal transacties of de verkeersintensiteit. Zo blijkt de bevolkingsgroei tussen 1980 en 2016 ruim 20\% te zijn. Het reëel bbp groeit in dezelfde periode met bijna $90 \%$.

We hebben een eenvoudige analyse toegepast, waarbij de bovenstaande productie-indicatoren in verband worden gebracht met de omvang van de bevolking en het bbp in constante prijzen. Daarnaast kijken we of er sprake is van een zekere trendmatige ontwikkeling. We vinden een significant statistisch verband met bevolking voor preventie, civiele en bestuursrechtelijke zaken en het aantal opgelegde transacties en schuldigverklaringen. Een significant verband met het bbp vinden we alleen voor het aantal opgelegde transacties en schuldigverklaringen. $\mathrm{Na}$ correctie voor de ontwikkeling van de bevolking en het bbp is er alleen bij preventie nog sprake van een trendmatige groei. Met andere woorden, in de loop der tijd zijn we er steeds beter in geslaagd misdrijven te voorkomen (na correctie voor de bevolkingsgroei). Voor de andere productievariabelen is zo'n trendmatige ontwikkeling statistisch niet vast te stellen. Veranderingen in de productie treden dus vooral op door allerlei incidentele gebeurtenissen of beleidsingrepen. Te denken valt aan de plotselinge instroom van asielzoekers uit voormalig Joegoslavië of een verzwaring van het strafklimaat. In paragraaf 2.2 noemden we nog verscheidene andere factoren die de omvang van de productie hebben beïnvloed en kennelijk belangrijker waren dan demografie en economie. De meeste daarvan zijn ook structureel, zoals individualisering, een toenemende complexiteit van de samenleving en een grotere mondigheid van burgers. 


\section{Allocatie van ingezette middelen}

\subsection{Kostenontwikkeling}

De ontwikkeling van de totale kosten en de kosten in de verschillende sectoren, gecorrigeerd voor de onderliggende loon- en prijsontwikkelingen, is weergegeven in figuur 2. Voor de berekeningswijze verwijzen we naar paragraaf 4.1.

\section{Figuur 2 Kostenontwikkeling V\&J en V\&J-sectoren, 1980-2016; gecorrigeerd} voor loon- en prijsontwikkelingen (indexcijfers: $1980=100$ )

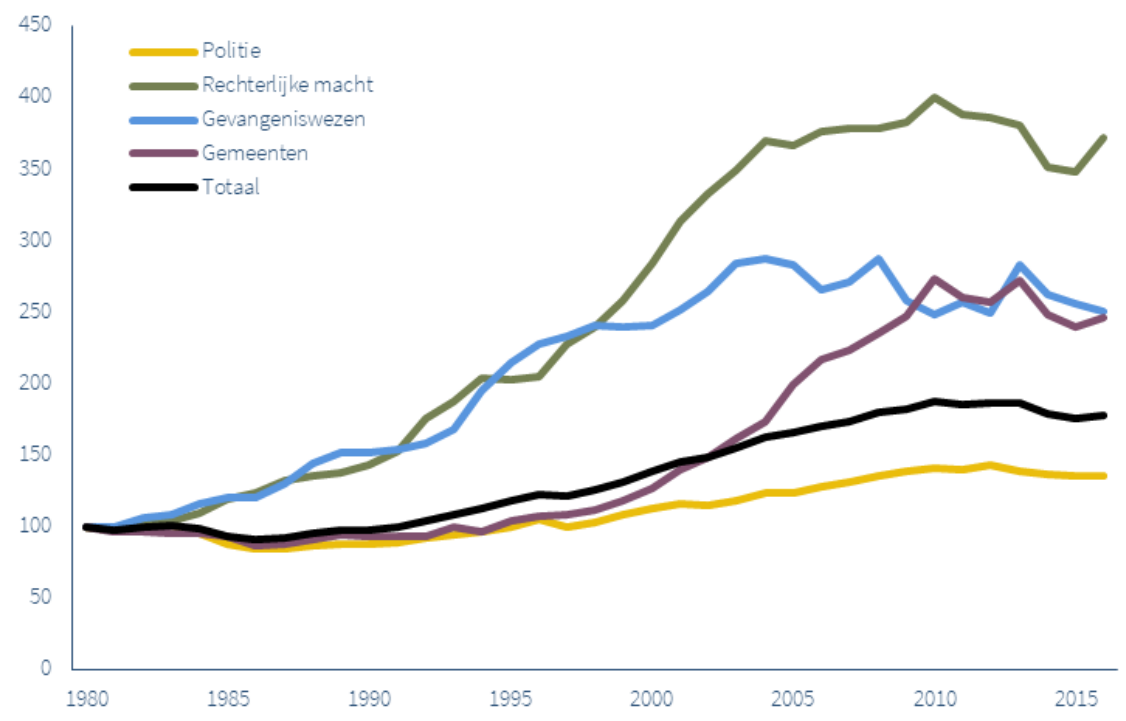

Uit figuur 2 blijkt dat de kosten tussen 1980 en 2016 fors stijgen. De totale kosten voor het beleidsterrein veiligheid en justitie groeien in de genoemde periode met bijna $80 \%$ (factor 1,8 ). De kosten zijn het sterkst gegroeid bij de rechterlijke macht (factor 3,8). De kosten voor het gevangeniswezen en de gemeenten groeien in die periode met een factor 2,5. De geringste kostengroei treffen we aan bij de politie (minder dan een factor 1,5).

\subsection{Allocatie van middelen tussen beleidsterreinen}

Uit figuur 2 blijkt dus dat in de onderzoeksperiode niet alleen de totale kosten groeien, maar dat ook de allocatie van de daarvoor benodigde middelen tussen de verschillende voorzieningen substantieel verandert. Figuur 3 geeft daarin nog beter inzicht door de kostenaandelen van iedere voorziening in het totaal van de kosten weer te geven. 
Figuur $3 \quad$ Kostenaandelen verschillende V\&J-voorzieningen in procenten, 1980-2016

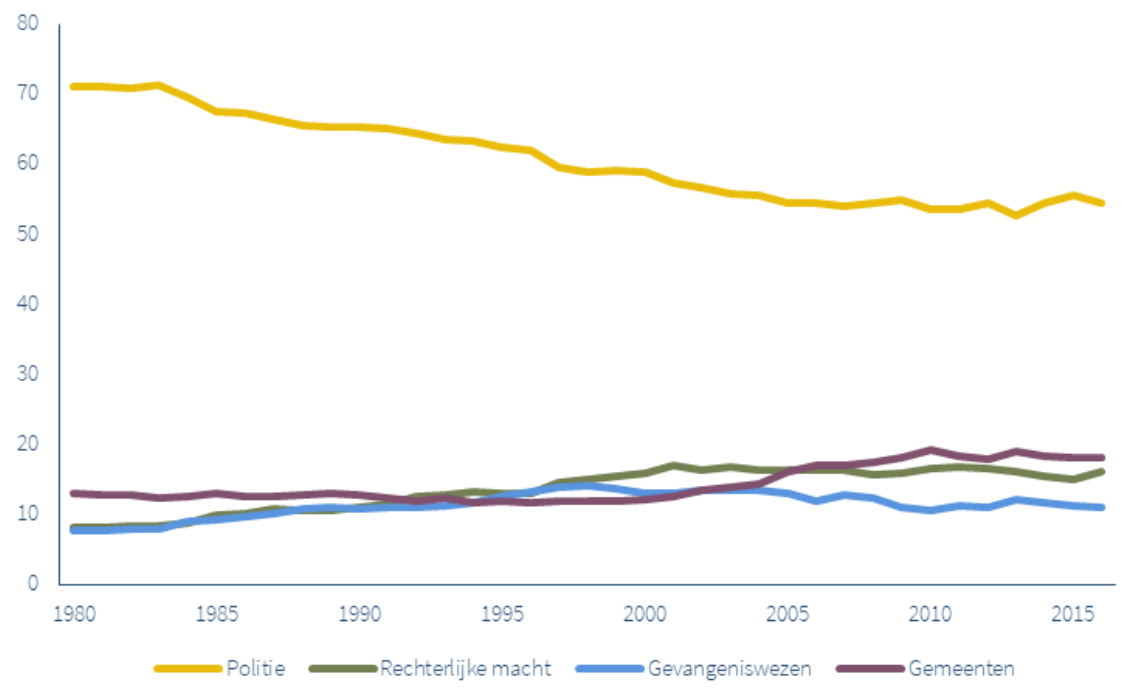

Figuur 3 laat zien dat het grootste deel van de kosten voor rekening komt van de politie. Dit aandeel neemt echter tussen 1980 en 2016 wel af: van ruim 70\% naar minder dan 55\%. De politie heeft dus in de loop der jaren ingeleverd ten opzichte van de andere V\&J-voorzieningen. Dat is voornamelijk het gevolg van de sterke kostenstijging bij de rechterlijke macht.

Het kostenaandeel van de rechterlijke macht verdubbelt in deze periode: van ongeveer $8 \%$ in 1980 naar 16\% in 2016. Het zijn vooral de civiele en bestuursrechtelijke zaken die een sterke groei te zien geven, vooral vanwege de samenhang met de omvang van de bevolking (in het bijzonder de vergrijzing).

Opvallend is ook de ontwikkeling van het kostenaandeel van gemeenten. Dit daalt in de beginperiode (tot 1999). Daarna groeit het kostenaandeel van 12\% in 1999 naar $19 \%$ in 2016. Gemeenten zetten in deze periode steeds meer middelen in voor andere activiteiten dan voor brandweer en rampenbestrijding. In 1999 ging dat nog om ongeveer $16 \%$ van alle gemeentelijke V\&J-kosten. In 2014 is dat aandeel gestegen naar ruim 36\%. Deze stijging is voor een belangrijk deel te verklaren uit de toenemende inzet van buitengewoon opsporingsambtenaren (boa's), ook wel gemeentelijke handhavers genoemd (Eikenaar \& Stokkom, 2014; Mein \& Hartmann, 2013). Daarnaast zijn gemeenten meer kosten gaan maken voor beleids- en planvorming op het terrein van openbare orde en veiligheid (OOV) (Cebeon, 2007). $\mathrm{Bij}$ het gevangeniswezen zien we een bescheiden groei van het kostenaandeel: van $8 \%$ in 1980 naar $12 \%$ in 2016 . Overigens ligt het kostenaandeel van het gevangeniswezen in 1997 een stuk hoger: $15 \%$.

Bovenstaande cijfers weerspiegelen de eerdergenoemde maatschappelijke ontwikkelingen. Deze komen vooral tot uitdrukking in de groei van het aantal civiele en 
bestuursrechtelijke zaken. Daarmee groeien uiteraard ook de middelen voor de rechtspraak.

Daarentegen zien we dat de criminaliteitscijfers in de afgelopen jaren steeds gunstiger zijn geworden. Na 2000 dalen de aantallen gewelds- en vermogensmisdrijven evenals veel andere misdrijven. Hierdoor neemt de druk op de politie niet verder toe. Daar staat wellicht tegenover dat er meer wordt ingezet op bijvoorbeeld de georganiseerde misdaad. Ook de hulpverlening kent in de loop der jaren nauwelijks groei. Blijkbaar houdt het Rijk hiermee rekening bij de allocatie van middelen en loopt de politie daardoor achter bij de andere sectoren. Voor een deel houdt dit ook verband met een andere invulling van de politietaken. De politie heeft er de afgelopen jaren vaak op gewezen dat toezicht en de aanpak van 'leefbaarheidsproblemen' niet tot de kerntaken van de politie zouden behoren. Deze ontwikkeling is gestimuleerd door de bestuurlijke opschaling bij de politie (eerst naar regio's en later naar het nationale niveau), waardoor meer nadruk komt te liggen op bovenlokale zaken (Stokkom \& Foekens, 2015). Gemeenten reageren hierop door een grotere rol te gaan spelen in het veiligheidsbeleid, met name door middel van de inzet van boa's en technologie. In feite ontstaat hierdoor weer een vorm van gemeentepolitie, zeker nu ook wordt gesproken over verruiming van de bevoegdheden van deze ambtenaren. De gemeente fungeert hier als substituut voor de (nationale) politie.

De dalende criminaliteit lijkt zich ook te vertalen in de ontwikkeling van het kostenaandeel gevangeniswezen. Zoals eerder aangegeven, is na 1997 sprake van een daling. Hierbij past wel een kanttekening. Door de toename van het aantal ernstige misdrijven en de verharding van het sanctiebeleid (meer vrijheidsstraffen en langer straffen) vindt er bij het gevangeniswezen tot 2010 een forse uitbreiding plaats van de productie (zie Blank \& Van Heezik, 2017). De productiviteit van het gevangeniswezen neemt in deze periode dan ook toe.

\section{$4 \quad$ Veiligheid en justitie: value for money?}

Uit het voorafgaande hebben we al indicaties dat verschillende reallocaties terug te voeren zijn op rationele afwegingen. In deze paragraaf bekijken we dit aan de hand van een analyse van de productiviteitsontwikkeling, zowel op systeem- als op sectorniveau.

\subsection{Model om de productiviteit te berekenen}

De productiviteit is niets anders dan de verhouding tussen de geleverde prestaties (productie of output) en de ingezette middelen. Omdat er verschillende producten en diensten zijn en verschillende typen ingezette middelen, moeten er eerst twee indices worden geconstrueerd om die vervolgens op elkaar te delen. De productiviteit is dan gelijk aan: 


\section{$\pi=\frac{\text { Index productie }}{\text { Index middelen }}=\frac{\text { Index productie }}{\text { Kosten } / \text { Prijsindex lonen en prijzen }}$}

Waarbij:

$\pi=$ productiviteit

Voor de index van ingezette middelen maken we gebruik van de totale kosten die gemoeid zijn met de geleverde productie. Omdat kosten mede worden bepaald door ontwikkelingen in lonen en prijzen corrigeren we hiervoor.

Om de index voor productie te bepalen maken we gebruik van een gewogen samenstelling van de onderliggende indicatoren. Zo tellen we alle genoemde productie-indicatoren op tot één (productie-)index. Iedere onderliggende productie-indicator krijgt daarbij een gewicht. Dit gewicht representeert in feite de maatschappelijke waarde die we aan het product toekennen. De gewichten voor de productie-indicatoren leiden we af uit een zogenoemde kostenfunctie en deze worden op een statistische manier bepaald. Kostenfuncties zijn geschikt om tegelijkertijd met verschillende prestaties en met verschillende ingezette middelen rekening te houden. Hoe een en ander precies in zijn werk gaat, is terug te vinden in de bijlagen van Blank en Van Heezik (2019).

\subsection{Productiviteitstrends}

Door toepassing van het bovenstaande model is de productiviteitsontwikkeling van het V\&J-systeem vanaf 1980 af te leiden. Figuur 4 presenteert het resultaat hiervan. Ook hier is het belangrijk te onderstrepen dat de geschetste ontwikkeling volgt uit een globale analyse met de nodige onzekerheden. 


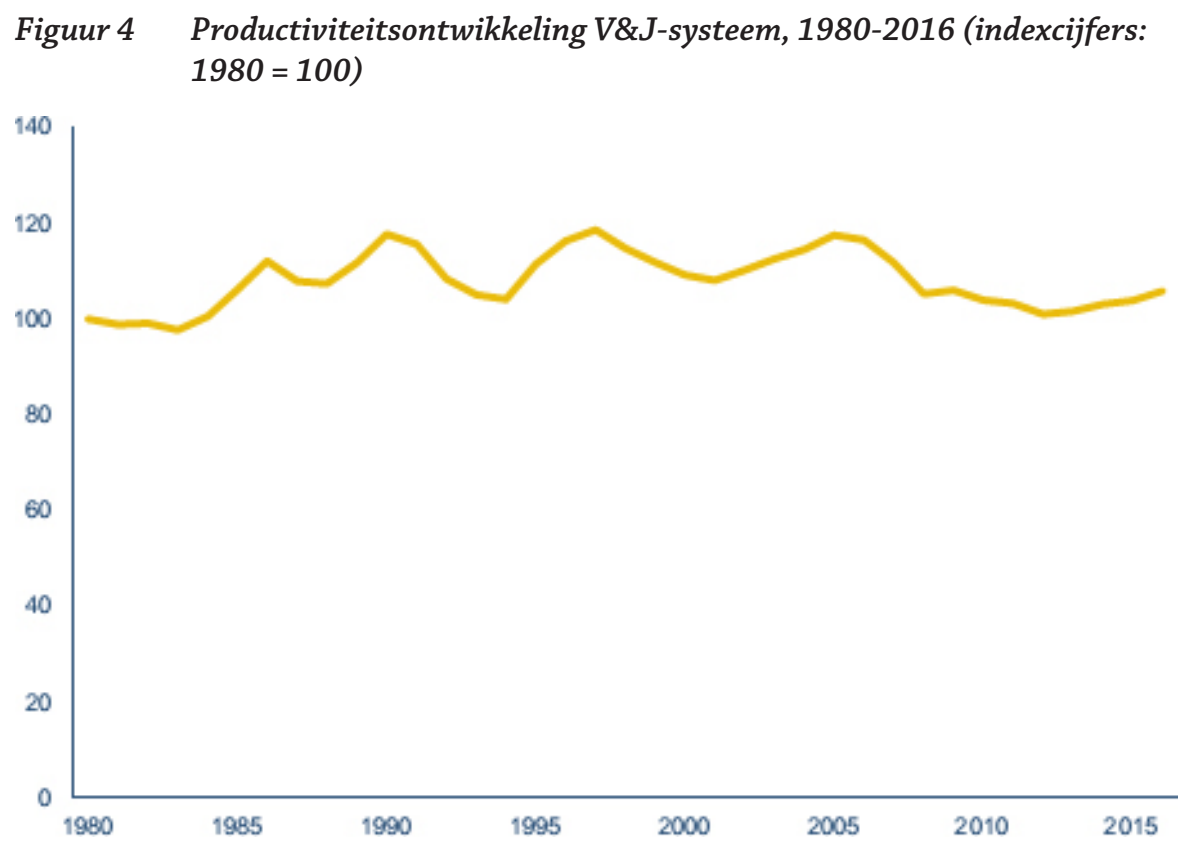

Figuur 4 laat zien dat de systeemproductiviteit in 2016 nauwelijks verschilt van het niveau van 1980. In de tussenliggende periode is wel sprake van ups en downs. Dit grillige patroon is voor een deel terug te voeren op de productiviteitsontwikkelingen van het gevangeniswezen. De sterke fluctuaties in het aantal gedetineerden is hier debet aan (Blank \& Van Heezik, 2017).

Vanuit systeemperspectief is het ook interessant na te gaan hoe de productiviteit van de sectoren zich ontwikkelt door wijzigingen in het systeem. Hiervoor maken we gebruik van een decompositie van de systeemproductiviteit. Het is mogelijk om de bijdrage aan de productiviteitsontwikkeling van ieder ingezet middel, in dit geval de sector, apart te berekenen (zie Blank \& Van Hulst, 2019). Dit betekent dat de productiviteitsontwikkeling afzonderlijk voor de politie, rechterlijke macht, gevangeniswezen en gemeenten is vast te stellen. Deze 'systeemtrends' zijn vervolgens te vergelijken met de ontwikkelingen van sectorproductiviteit, zoals gepresenteerd in de database https://TrendsinPubliekesector.nl (TiPS). Het verschil tussen beide is te interpreteren als de bijdrage van de afzonderlijke sectoren aan de systeemproductiviteit.

Het verschil tussen beide begrippen volgt uit het hanteren van verschillende productie-indicatoren. $\mathrm{Zo}_{\mathrm{o}}$ is een door de politie opgehelderd misdrijf een prestatie voor de sector politie, maar niet voor het systeem. Daar levert de opheldering pas iets op in termen van productie als de opheldering ook daadwerkelijk tot een sanctie leidt. Dit betekent dat een sector op zichzelf heel productief kan zijn, maar in termen van het systeem juist niet. Als een opheldering niet tot een sanctie leidt, zijn eigenlijk alle inspanningen van de politie voor niets geweest. Het systeem heeft hier geen eindproduct kunnen leveren. Door de systeem- en sectorproductiviteit te vergelijken, ontstaat een beeld van dit soort systeemmanco's. 
Voor de overzichtelijkheid presenteren we per sector de beide productiviteitscijfers, de sector- en systeemproductiviteit, afzonderlijk (figuur 5, 6 en 7). Voor gemeenten kunnen we deze vergelijking niet maken, omdat we die in de eerdere studie niet in de analyse betrokken. Figuur 5 toont de ontwikkelingen van de sector- en systeemproductiviteit van de politie.

Figuur 5 Systeem- versus sectorproductiviteit politie, 1980-2016 (indexcijfers $1980=100)$

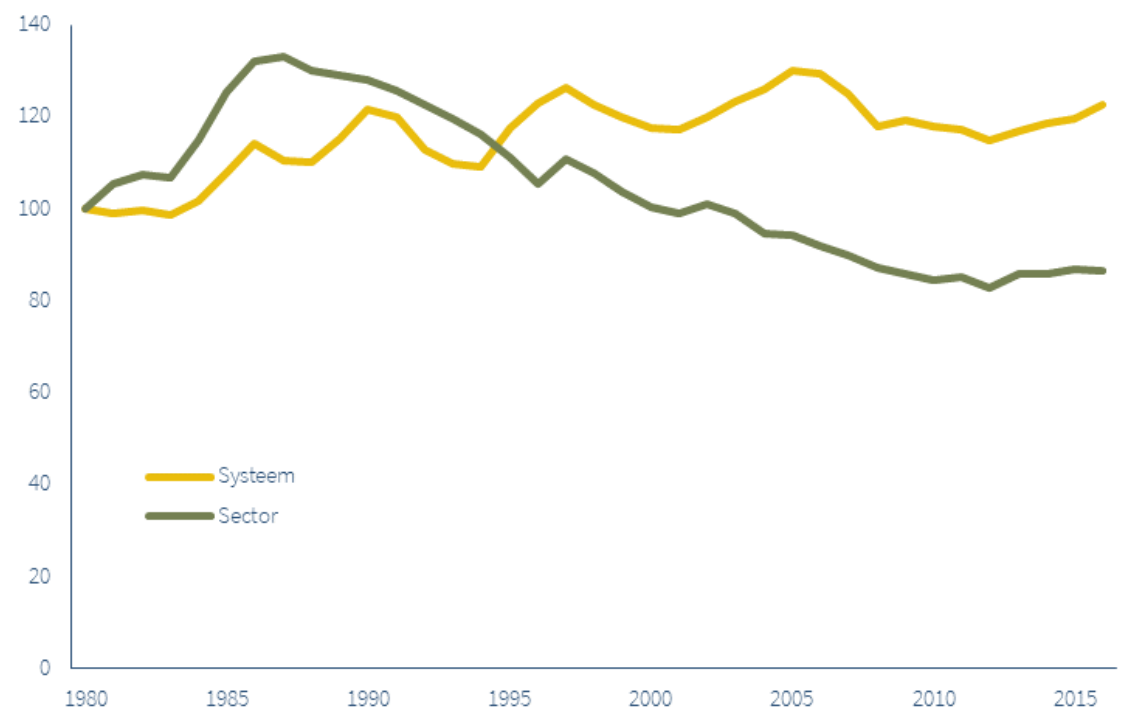

Figuur 5 laat zien dat de systeemproductiviteit van de politie tot 1995 achterblijft bij de sectorproductiviteit. Dit is een indicatie dat de productiviteitsgroei bij de politie zelf zich niet vertaalt in een evenredige verbetering van de systeemproductiviteit. Blijkbaar zijn er ontwikkelingen in het systeem geweest die de productiviteitsgroei bij de politie deels tenietdoen. Na deze periode zien we juist dat de sectorproductiviteit sterk achterblijft bij de systeemproductiviteit. De ontwikkeling van de productiviteit bij de politie zelf daalt zonder negatieve gevolgen voor de systeemproductiviteit. De negatieve productiviteitsontwikkeling wordt dus enigszins gemitigeerd door het systeem. Dat is vooral te zien in de periode 1994-1996 en 2001-2005.

De periode 1994-1996 is de periode direct na invoering van de Politiewet 1993. De negatieve ontwikkeling van de sectorproductiviteit heeft waarschijnlijk vooral te maken met de inzet van extra middelen voor de transitie, terwijl de nieuwe organisatie waarschijnlijk al wel heeft bijgedragen aan een beter functioneren van de keten. Een van de argumenten voor de Politiewet 1993 was juist het op regionaal niveau versterken van de driehoek tussen gemeente, politie en OM. In de periode 2001-2005 'profiteert' de politie juist van een sterke groei elders in de keten. Deze periode kenmerkt zich door een sterke verhoging van de gemiddelde strafmaat. Als deze verhoging vooral een gevolg is van een strenger strafklimaat (en niet van een 
zwaardere casemix), levert het systeem meer productie zonder dat de politie hiervoor extra inspanningen hoeft te leveren. De politie levert immers alleen maar verdachten aan het systeem, waarbij de inspanningen niet afhangen van welke straf deze verdachte uiteindelijk krijgt. De extra inspanningen komen ten laste van het gevangeniswezen.

Figuur 6 geeft de sector- en systeemproductiviteit van de rechterlijke macht weer.

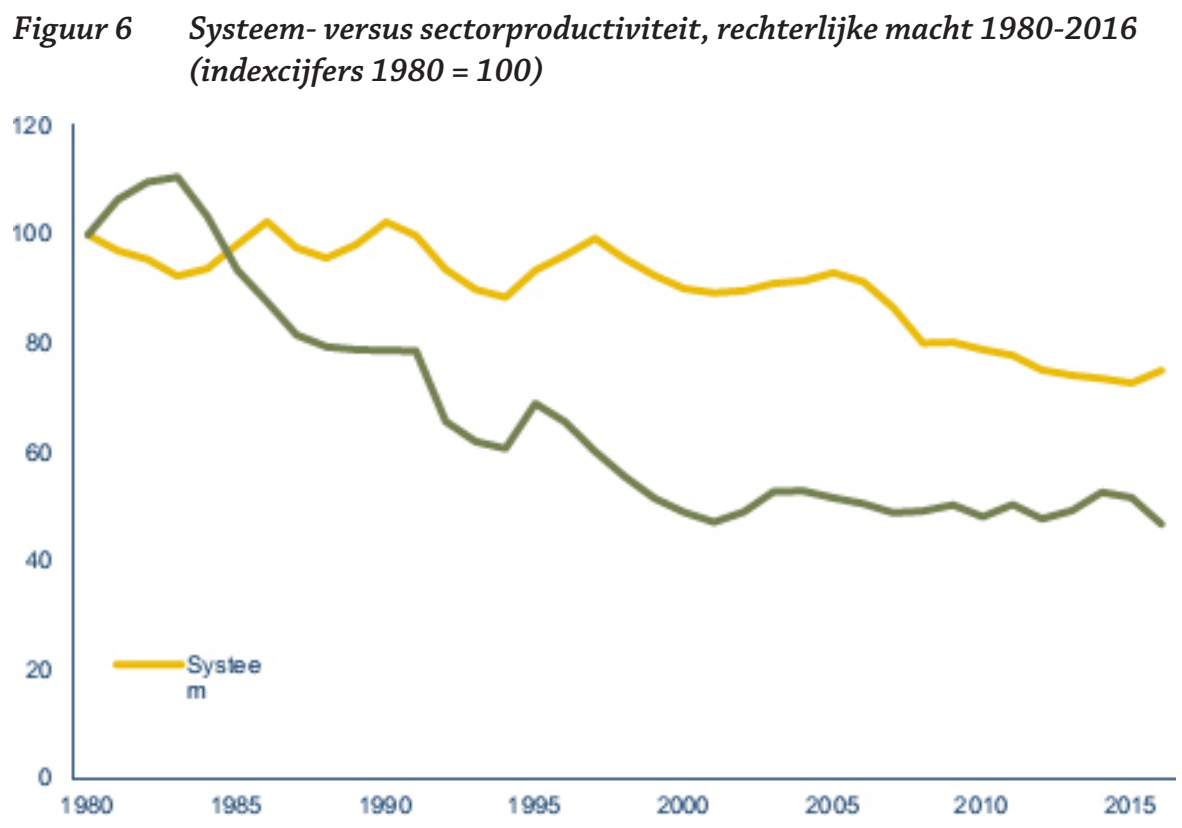

Uit figuur 6 blijkt dat de systeemproductiviteit van de rechterlijke macht tussen 1980 en 2016 met 25\% daalt. Dit is vooral het gevolg van de alsmaar dalende productiviteit van de rechterlijke macht zelf. De daling hiervan bedraagt in de onderzoeksperiode meer dan $50 \%$. Het verschil tussen de sector- en systeemproductiviteit is voor een groot deel toe te rekenen aan de al eerder gememoreerde toegenomen strafmaat. Het uitspreken van een zwaardere straf in vergelijkbare gevallen is een extra prestatie (in systeemtermen) die bijna 'gratis' is. Zoals eerder aangegeven, komen de kosten voor het zwaarder straffen voornamelijk te liggen bij het gevangeniswezen. Opvallend is wel dat de sectorproductiviteit van de rechterlijke macht na 2003 nagenoeg constant is, terwijl deze trendbreuk in de systeemproductiviteit niet terug te vinden is. Blank en Van Heezik (2017) geven aan dat de omslag na 2001 vooral te maken heeft met een sterkere focus op de bedrijfsvoering, voornamelijk door de oprichting van de Raad voor de rechtspraak. Dit effect zien we niet terug in de systeemproductiviteit, omdat na 2004 weer sprake is van een forse daling in de gemiddelde strafmaat.

Figuur 7 presenteert de ontwikkelingen in systeem- en sectorproductiviteit van het gevangeniswezen. 
Figuur 7 Systeem-versus sectorproductiviteit, gevangeniswezen 1980-2016 (indexcijfers: $1980=100$ )

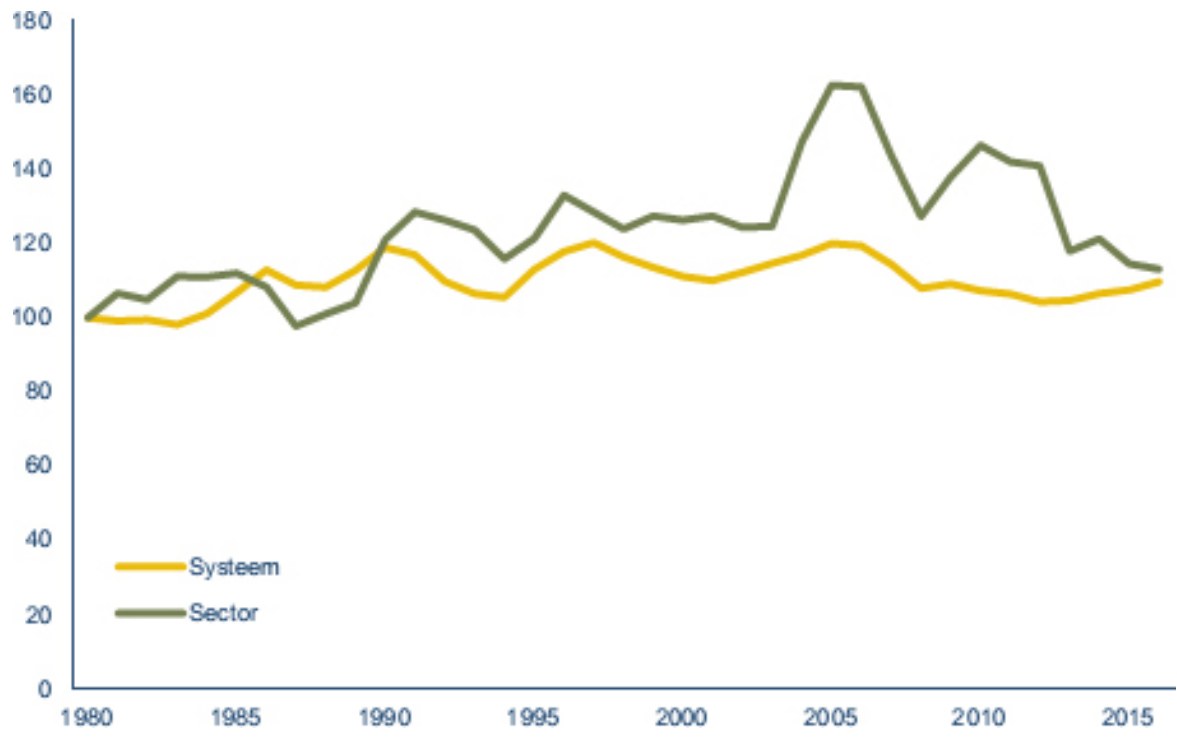

Uit figuur 7 blijkt dat beide productiviteitsmaten redelijk met elkaar in de pas lopen. Door de jaren heen groeien zij allebei met ongeveer 13\%. Overigens is dit niet vreemd, omdat we zowel bij de meting van de sectorproductiviteit als bij die van de systeemproductiviteit het aantal gedetineerden als productie-indicator hanteren. Het is ook duidelijk dat een verandering in de gemiddelde strafmaat (en dus in de productie) direct van invloed is op de kosten voor het gevangeniswezen. Deze eenop-een relatie ontbreekt bij politie en rechterlijke macht.

\subsection{De allocatie van middelen}

De schattingsresultaten bieden ook de mogelijkheid om te kijken of de allocatie van middelen in de loop van de tijd afwijkt van de geschatte (optimale) allocatie. Als dat het geval is, dan is er sprake van een onder- of overgebruik van een specifiek ingezet middel. We spreken dan van misallocaties. Uit deze analyse blijkt dat er vooral in de periode tot ongeveer het jaar 2000 aanzienlijke afwijkingen zijn. Zo is er een aanzienlijk overgebruik van politie in de beginjaren van de onderzoeksperiode. Daar is vanaf midden jaren negentig een forse correctie op uitgevoerd. Tegelijkertijd zien we een ondergebruik van de rechterlijke macht en het gevangeniswezen. Daar zijn vanaf midden jaren negentig juist extra middelen toegevoegd. Opvallend is verder dat er in de jaren negentig een aanzienlijk ondergebruik van de gemeentelijke middelen ontstaat, dat eerst gecorrigeerd wordt en later (vanaf 2010) omslaat in een overgebruik. Het lijkt erop dat door de Politiewet in 1993 (en al eerdere bezuinigingen) de politie relatief moet inleveren ten opzichte van andere sectoren. Door de reorganisatie in 1993 verschuift de aandacht van het lokale naar het regionale niveau. Gemeenten vullen dit gat op lokaal niveau op en lijken daar na verloop van tijd in door te schieten. In de meest recente jaren volgt daar weer 
een correctie op. Het is interessant om te zien dat er in de meest recente periode geen misallocaties meer zijn.

\subsection{Gevoeligheidsanalyse: de invloed van de strafmaat}

In paragraaf 2 gaven we aan dat we met de productiemaat 'aantal gedetineerden' in feite het aantal strafjaren tot uitdrukking brengen. De groei hiervan kan een indicatie zijn van een toename van het aantal misdrijven waarvoor een vrijheidsstraf wordt opgelegd of van de ernst daarvan, maar ook van een verhard strafklimaat. In het laatste geval betekent dit dat het systeem eenzelfde aantal straffen produceert, maar dat het wel meer is gaan kosten vanwege de toegenomen strafmaat. In dat geval zou de productiviteit dalen. De strafmaat is van wezenlijke betekenis, vanwege de grote mate van fluctuatie door de jaren heen, zoals uit figuur 8 blijkt. De strafmaat - gemiddelde strafduur in dagen - wordt hier gemeten door het aantal gedetineerden te vermenigvuldigen met 365 en te delen door de totale instroom in een jaar.

Een alternatieve aanpak voor het bepalen van het gemiddeld aantal detentiedagen is uit te gaan van de door de rechters opgelegde strafduur van het onvoorwaardelijke deel van de vrijheidsstraf, waarbij het deel dat op grond van de VI-regeling (voorwaardelijke invrijheidsstelling) niet wordt uitgezeten van de strafduur is afgetrokken. Dit levert een iets ander beeld op, maar het patroon is ongeveer hetzelfde (zie ook figuur 8).

\section{Figuur 8 Ontwikkeling gemiddelde strafduur in dagen, 1980-2016}

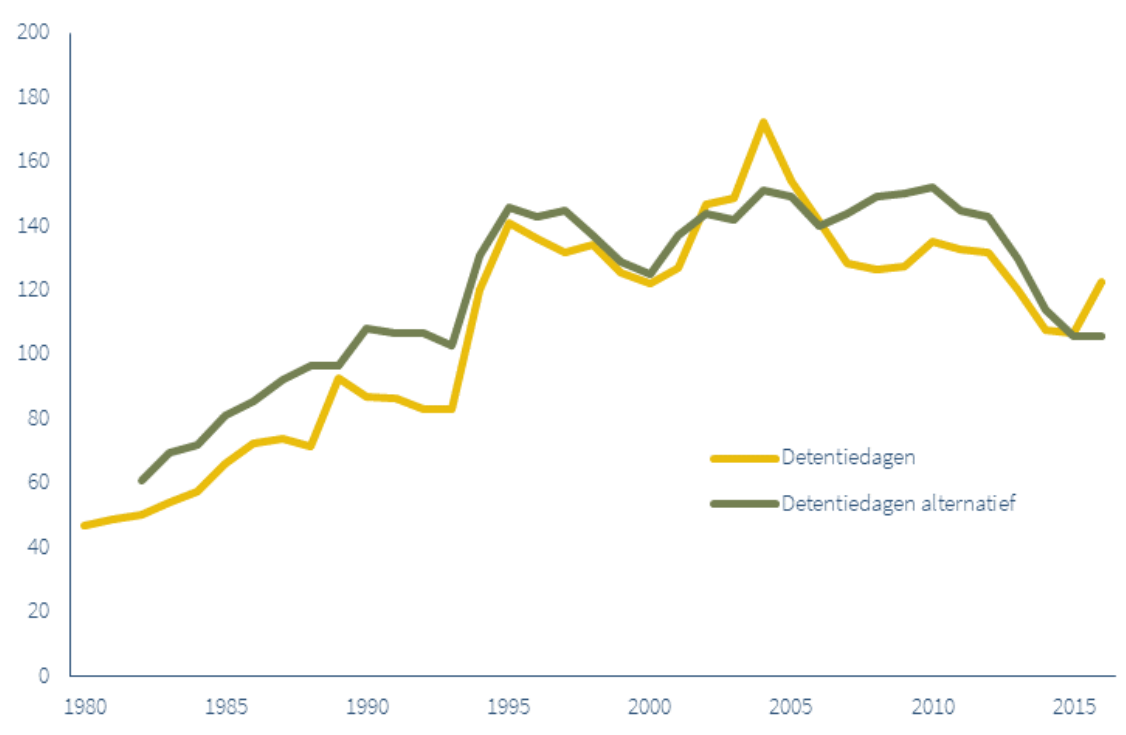

Uit figuur 8 wordt duidelijk hoe sterk de gemiddelde strafmaat tussen 1980 en 2016 groeit. Vooral tot 1995 is er een grote stijging van het gemiddeld aantal detentiedagen. In de periode daarna zien we eerst een dalende trend, maar na 2000 is er weer een stijgende lijn waar te nemen. Vanaf 2010 neemt het aantal detentieda- 
gen af. Aan deze ontwikkeling liggen verschillende andere ontwikkelingen ten grondslag:

- het vervangen van lichte vrijheidsstraffen door transacties, geldboetes en taakstraffen;

- het zwaarder straffen van gedetineerden voor hetzelfde vergrijp;

- de toename van het aandeel ernstige misdrijven bij de opgelegde straffen.

Er zijn onvoldoende consistente gegevens over de gehele periode beschikbaar om de ontwikkeling van de strafmaat nauwkeurig te ontleden in deze drie factoren. Wel kunnen we enige indicaties geven. Zo is er inderdaad sprake van een forse groei van het aantal taakstraffen (Poort \& Zengerink, 2009). Tegelijkertijd leggen de rechters vaker en steeds zwaardere vrijheidsstraffen op. Zo neemt de duur van de door de rechter opgelegde onvoorwaardelijke vrijheidsstraffen (die daadwerkelijk moeten worden uitgezeten) vanaf begin van de jaren tachtig tot 1995 sterk toe. Dit geldt voor veel delicten, maar vooral voor ernstige misdrijven als geweldsmisdrijven (Grapendaal et al., 1997; Van der Heide \& Eggen, 2003; Kommer, 1994; Van Velthoven, 2014).

Wijzigingen in het strafklimaat spelen dus wel degelijk een rol, al verklaren ze niet alle veranderingen in de strafmaat. Als we geen rekening willen houden met deze veranderingen in strafklimaat, dan kunnen we de instroom van gedetineerden als productiemaat gebruiken. Figuur 9 presenteert de productiviteitsontwikkeling op basis van deze alternatieve productie-indicator.

Figuur 9 Productiviteitsontwikkeling V\&J-systeem op basis van instroom gedetineerden in plaats van aantal gedetineerden, 1980-2016 (indexcijfers: $1980=100$ )

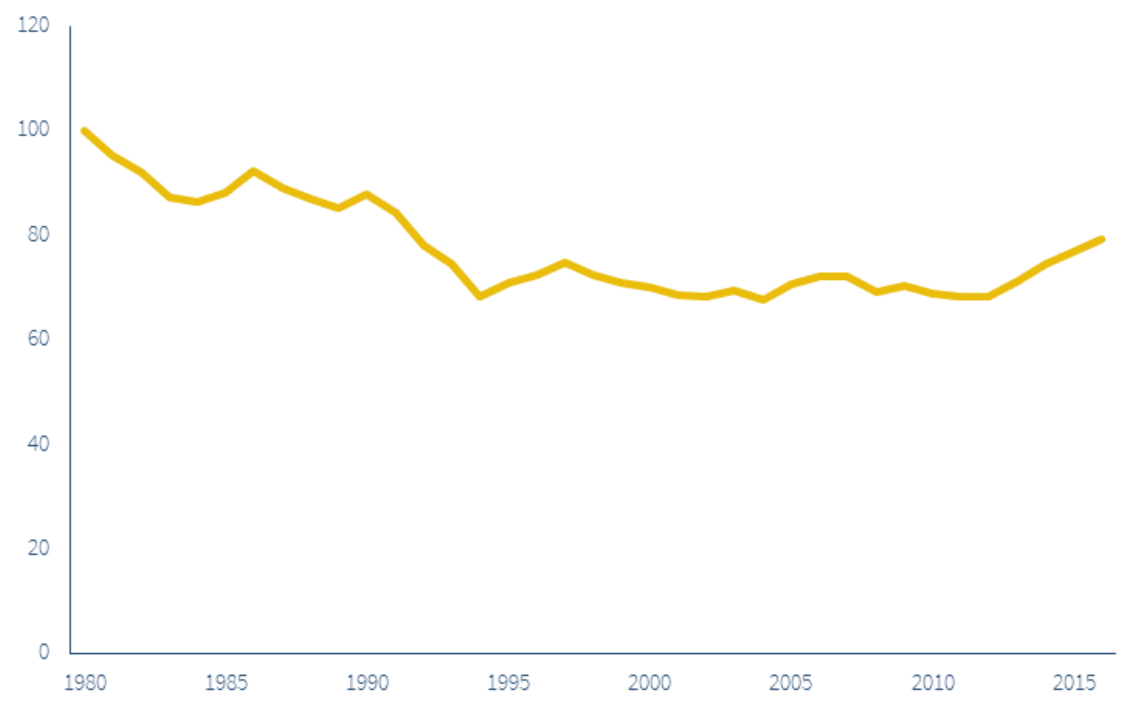


Figuur 9 laat, zoals verwacht, een ander beeld zien dan figuur 4. Over de gehele periode 1980-2016 is er nu een daling van de productiviteit te zien met 20\%. Deze daling treedt vooral op in de periode tussen 1980 en 1994. Dit loopt nagenoeg synchroon met de ontwikkeling van de strafmaat (zie figuur 8). Hiermee wordt duidelijk wat de gevolgen zijn van een verhard strafklimaat (voor zover daarvan sprake is) op de gemeten productiviteit.

Wanneer we de productiviteitsontwikkeling zouden kunnen berekenen aan de hand van gedetailleerdere cijfers over de ernst van de misdrijven en het vigerende strafklimaat, dan levert dat waarschijnlijk een figuur op die ergens tussen de figuren 4 en 9 in ligt. Dat betekent dat de huidige productiviteit van het V\&J-systeem in vergelijking met 1980 nauwelijks is verbeterd.

\section{Conclusies}

Uit eerder onderzoek van IPSE Studies bleek dat de productiviteit van veiligheid en justitie zich in de afgelopen decennia niet goed ontwikkelde. Vooral de productiviteitsontwikkeling bij politie en rechterlijke macht was teleurstellend.

De terugblik op de V\&J-productiviteitsontwikkeling vanuit systeemperspectief levert een iets positiever beeld op. In het gunstigste geval krijgt de burger in 2016 nog evenveel 'waar' geleverd voor zijn belastinggeld als in 1980, maar waarschijnlijk iets minder (afhankelijk van de gekozen indicatoren). Het V\&J-systeem als zodanig functioneert dus beter dan de som der delen (de afzonderlijke sectoren/voorzieningen). Blijkbaar is er een aantal systeemmaatregelen genomen die blijken te werken. Zonder dat er harde statistische bewijzen kunnen worden geleverd met de huidige data, zijn de bestuurlijke aanpassingen, die de coördinatie tussen gemeenten, politie en rechterlijke macht moesten verbeteren, waarschijnlijk effectief geweest. Te denken valt aan een meer integrale benadering van problemen, werken in netwerken (in plaats van alleen in ketens), de opkomst van lokaal veiligheidsbeleid en sturing op basis daarvan, en bestuursrecht als aanvulling op strafrecht. Denk bij het laatste aan de toename van bestuursrechtelijke bevoegdheden van de burgemeester om de openbare orde te handhaven, toepassing van de Wahv en de betere (digitale) overdracht van zaken in de (justitiële) keten.

Verder zijn er aanwijzingen dat er in de loop van de tijd sprake is van herallocaties van middelen over de verschillende sectoren. De politie heeft vooral in de jaren negentig relatief moeten inleveren ten opzichte van de rechterlijke macht en het gevangeniswezen. De schattingen geven een indicatie dat er in de jaren tachtig een overgebruik van politie was en dat deze herallocaties op zijn plaats waren. In de meest recente periode lijken de allocaties veel meer in balans. Ook hieruit kan worden geconcludeerd dat de productiviteit is verbeterd. Het is niet uit te sluiten dat in de nabije toekomst weer herallocaties plaatsvinden door bijvoorbeeld een sterke prioritering voor het bestrijden van de georganiseerde misdaad.

Ook hebben er nog herallocaties plaatsgehad vanwege een duidelijke taakverzwaring bij sommige sectoren. Meest in het oog springend is het sterk toegenomen aantal civiele en bestuursrechtelijke zaken, waardoor de rechterlijke macht meer middelen absorbeert. In de loop der tijd worden relatief ook meer middelen ingezet 
bij gemeenten. Waar vroeger de kosten van gemeenten vooral bestonden uit die voor de brandweer en rampenbestrijding, maken andere kosten voor openbare orde en veiligheid (waaronder boa's) een steeds groter deel van de gemeentelijke kosten uit. Een deel van de politietaken is daarmee weer bij gemeenten terechtgekomen.

We willen hierbij benadrukken dat het productiviteitscijfer op zichzelf niet een soort rapportcijfer is voor het functioneren van de verschillende sectoren. Er is wellicht een aantal maatschappelijke ontwikkelingen die het werk lastiger hebben gemaakt waarmee we in onze rekenexercitie niet voldoende rekening houden. Te denken valt aan de veel complexere problemen, zwakkere sociale controle en een minder zelfredzame samenleving. Ook de huidige coronacrisis is hier een goed voorbeeld van. De rechterlijke macht heeft een tijd op halve kracht gewerkt, terwijl politie en boa's overuren draaiden om de coronaregels te handhaven. Evenementen gingen daarentegen niet door en ook door uitstel en afstel van rechtszaken vermindert de druk op het gevangeniswezen. Ongetwijfeld zal er ook een inhaalslag gemaakt gaan worden. Het laat zich lastig voorspellen wat het effect hiervan is op de productiviteit. We willen veel meer het punt benadrukken dat het beleid met nieuwe maatregelen dikwijls claimt de productiviteit te bevorderen en we dat vervolgens niet terugzien in een breuk in de cijfers. Dat geeft te denken.

\section{Literatuur}

Aarts, L.T. (2018) Prestatie-indicatoren voor verkeersveiligheid (SPI's). Overzicht van beschikbare kennis over SPI's als basis voor risicogestuurd beleid. Den Haag: SWOV.

Bax, C.A. (2012) Historie en toekomst: ruim honderd jaar verkeersveiligheidsbeleid en -kennis in Nederland. Den Haag: SWOV.

Blank, J.L.T. \& A.A.S. van Heezik (2017) Productiviteit van overheidsbeleid, deel III: de Nederlandse veiligheid en justitie, 1980-2014. Den Haag/Delft: Eburon.

Blank, J.L.T. \& A.A.S. van Heezik (2019) Productiviteit en allocatie op het terrein van veiligheid en justitie, 1980-2016. Delft: IPSE Studies. Retrieved from www.ipsestudies.nl/wpcontent/uploads/2019/06/IPSE1801-4.pdf.

Blank, J.L.T. \& B.L. van Hulst (2017) Balancing the health workforce: breaking down overall technical change into factor technical change for labour - an empirical application to the Dutch hospital industry. Human Resources for Health, 15(1), 15. doi.org/10.1186/ s12960-017-0184-5.

Cebeon (2007) Onderzoekstraject Openbare Orde en Veiligheid. Uitgavenontwikkeling 20012005 Herijking verdeling gemeentefonds en BDUR. Amsterdam: Cebeon.

Eikenaar, T. \& B. van Stokkom (2014) Van stadswacht naar nieuwe gemeentepolitie? Gemeentelijk toezicht en handhaving in de openbare ruimte. Amsterdam: Reed Business.

Eshuis, R.J. \& B.J. Diephuis (2018) Civiele rechtspraak. Factsheet 2018-1. Den Haag: Wetenschappelijk Onderzoek- en Documentatiecentrum.

Grapendaal, M., P.P. Groen \& W. van der Heide (1997) Duur en volume. Ontwikkeling van de onvoorwaardelijke vrijheidsstraf tussen 1985 en 1995: feiten en verklaringen. Den Haag: WODC.

Heide, W. van der \& A.T.J. Eggen (2003) Criminaliteit en rechtshandhaving 2001. Den Haag: WODC/Boom Juridische uitgevers.

Kommer, M.M. (1994) Het Nederlandse strafklimaat in internationaal perspectief. In: M. Moerings (red.), Hoe punitief is Nederland? Arnhem: Gouda Quint bv. 
Mein, A.G. \& A.R. Hartmann (2013) De stand van het boa-bestel. Eindrapport over het stelsel waarbinnen buitengewoon opsporingsambtenaren functioneren. Utrecht: Verwey-Jonker Instituut.

Poort, R. \& J. Zengerink (2009) De reclassering en de werkstraf. Tijdschrift Sancties, 158168.

Stokkom, B. van \& P. Foekens (2015) Stadshandhavers Bouwstenen voor de inrichting van handhaving in de openbare ruimte. Den Haag: WODC / Ministerie van Veiligheid en Justitie.

Tulder, F.P. van (2014) Daling instroom civiele handelszaken onderzocht. Memorandum 2014-4. Den Haag: Wetenschappelijk Onderzoek- en Documentatiecentrum.

Tulder, F. van, D. Moolenaar \& J. van der Schaaf (2017) Beroep op de rechter daalt aanzienlijk door verhoging griffierechten. ESB, 102 (september), 436-438.

Urlings, T., J.L.T. Blank \& T.K. Niaounakis (2014) Doelmatige dienders. Een vergelijking tussen regiokorpsen van de Nederlandse politie in de 21e eeuw (IPSE Studies Research Reeks No. 2014-2). Delft: IPSE Studies.

Velthoven, B. van (2014) Straftoemeting door de rechter in de periode 1995-2012. Leiden: Leiden University.

Wijnen, W., W.A.M. Weijermars \& Y.R. Bos (2013) Update effectiviteit en kosten van verkeersveiligheidsmaatregelen. Den Haag: SWOV. 